\title{
Crude Protein Equivalence Value of a Multi- Enzyme Product for 28- and 42-Day-Old Broilers
}

Technical Note

\section{author(s)}

Malakzadegan A*

Zaghari $\mathrm{M}^{\top}$

Khalaji $S^{1}$

Shivazad $\mathrm{M}^{1}$

'Department of Animal Science, College of Agriculture and Natural Resource, University of Tehran, Karaj31587-11167, Iran

\section{-Mail Adress}

*Corresponding author's name and address: A. Malakzadegan, Department of Animal Science, University College of Agriculture and Natural Resources, University of Tehran, 31587-11167, Karaj, Iran.

Telephone: +98 261 2248082;

FAX +98 2612246752 .

Email: ahmad_malakzadegan@yahoo.com

\section{-Keywords}

Multi enzyme, y equivalent value, crude, broiler.

\section{ABSTRACT}

In order to estimate the crude protein (CP) equivalence value of Natuzyme-p (NP) enzyme by using regression response equations, two experiments were carried out using Ross (308) broiler chicks. Graded levels of dietary CP (while amino acids levels were kept constant) and $\mathrm{NP}$ enzyme were used to derive the regression equation in the first experiment. Four levels of dietary CP and NP enzyme were fed to 160 feather-sexed male broiler chicks during the starter (0-28 $d$ of age) and grower (28-42 d of age) period. Each diet was offered to four replicates of five chicks in a completely randomized design. Results obtained in experiment one failed to fit a regression equation between BW, dietary CP levels and NP enzyme. In experiment two, graded levels of CP changed along with the levels of lysine (Lys), Met+Cys and threonine (Thr). Regression equations between BW and dietary CP and NP enzyme were derived. Nonlinear and linear equations were generated for enzyme and CP. Based on an assessment of $r^{2}$ and $P$ value, nonlinear equations were used to determine enzyme equivalence. The derived regression equations of body weight for $\mathrm{CP}$ were set to be equal with those obtained for NP and were solved; enzyme equivalence value for $\mathrm{CP}$ was calculated by subtracting the obtained value from CP content of basal diet. Crude protein equivalence value of NP at 28 and $42 \mathrm{~d}$ of age was estimated to be 0.96 and $0.38 \%$, respectively.

\section{INTRODUCTION}

Several benefits of the supplementation of broiler diets with mixtures of exogenous enzymes have been reported. They may improve nutrient digestibility, reduce nitrogen and phosphorus excretion, allow the use of alternative feed ingredients, reduce variations in the nutritional quality of feed ingredients, and reduce the incidence of wet litter that commonly happens when diets rich in viscous grains are fed (Yu \& Chung 2007). However, determining nutrient equivalence values of enzymes is a requisite for precise feed formulation. Although $P$ equivalence values of microbial phytase are well established (Cohelho \& Kornegay 1996), corresponding data on amino acid and CP release with added phytase and multi-enzyme products are limited. The lysine equivalence of phytase was determined (Ravindran et al., 2001), but the effect of phytase alone or together with other exogenous enzymes on the other amino acids is of considerable practical significance and needs to be quantified to enable its inclusion in least-cost diet formulation.

Estimates of nutrient equivalence value of exogenous phytase using regression equations were reported in pigs (Jendza, 2006; Radcliff, 2006) and broilers (Jendza, 2006; Adedokun, 2004). Zaghari et al. (2008) determined the crude protein equivalence of a multi-enzyme product (containing phytase: $1500 \mathrm{U} / g$, beta-glucanase: $700 \mathrm{U} / g$, alpha- 
Table 1 - Ingredientsrientnutritional composition of experimental diets (0-28 and 28-42 d of age, Exp. 1)

\begin{tabular}{|c|c|c|c|c|c|c|c|c|}
\hline \multirow[t]{2}{*}{ Ingredients } & \multicolumn{4}{|c|}{ Starter period (0-28 d of age) } & \multicolumn{4}{|c|}{ Grower period (28-42 d of age) } \\
\hline & 1 (basal diet) & 2 & 3 & 4 & 1 (basal diet) & 2 & 3 & 4 \\
\hline Corn & 653.3 & 644.1 & 601.17 & 559.3 & 722.5 & 713.3 & 670.9 & 634.1 \\
\hline Soybean Meal & 195.3 & 264.9 & 277.6 & 290.3 & 116.3 & 186 & 198.7 & 202.7 \\
\hline Corn gluten & 1.9 & 6.1 & 38.6 & 71.1 & 17.1 & 22.7 & 55.2 & 92.3 \\
\hline Rice Bran & 60 & 0 & 0 & 0 & 60 & 0 & 0 & 0 \\
\hline Corn oil & 30 & 30 & 30 & 30 & 30 & 30 & 30 & 28 \\
\hline Dicalcium phosphate & 18.8 & 18.5 & 18.2 & 17.9 & 16.7 & 16.3 & 16 & 15.8 \\
\hline Oyster shell & 14.1 & 13.9 & 14 & 14.1 & 12.6 & 12.4 & 12.5 & 12.6 \\
\hline $\mathrm{NaCl}$ & 2.4 & 2.4 & 2.4 & 2.4 & 0.9 & 0.9 & 0.9 & 0.9 \\
\hline $\mathrm{NaHCO}_{3}$ & 1 & 1 & 1 & 1 & 3.2 & 3.2 & 3.2 & 3.2 \\
\hline Min. premix ${ }^{1}$ & 3 & 3 & 3 & 3 & 3 & 3 & 3 & 3 \\
\hline Vit. Premix ${ }^{1}$ & 3 & 3 & 3 & 3 & 3 & 3 & 3 & 3 \\
\hline DL-Methionine & 5 & 4.2 & 3.2 & 2.2 & 5.4 & 3.1 & 2 & 1 \\
\hline L-Lysine & 8.4 & 6.2 & 5.4 & 4.6 & 6.9 & 4.6 & 3.8 & 3.3 \\
\hline L-Threonine & 3.7 & 2.7 & 2 & 1.2 & 2.5 & 1.5 & 0.8 & 0.1 \\
\hline \multicolumn{9}{|l|}{ Nutrients } \\
\hline $\mathrm{AME}_{n}$ & 3050 & 3050 & 3050 & 3050 & 3150 & 3150 & 3150 & 3150 \\
\hline Crude protein & 16 & 18 & 20 & 22 & 14 & 16 & 18 & 20 \\
\hline $\mathrm{Ca}$ & 0.97 & 0.97 & 0.97 & 0.97 & 0.85 & 0.85 & 0.85 & 0.85 \\
\hline $\mathrm{NPP}^{2}$ & 0.47 & 0.47 & 0.47 & 0.47 & 0.42 & 0.42 & 0.42 & 0.42 \\
\hline $\mathrm{Na}$ & 0.16 & 0.16 & 0.16 & 0.16 & 0.16 & 0.16 & 0.16 & 0.16 \\
\hline Lysine & 1.4 & 1.4 & 1.4 & 1.4 & 1.09 & 1.09 & 1.09 & 1.09 \\
\hline Met+Cys & 1 & 1 & 1 & 1 & 0.86 & 0.86 & 0.86 & 0.86 \\
\hline Threonine & 0.94 & 0.94 & 0.94 & 0.94 & 0.74 & 0.74 & 0.74 & 0.74 \\
\hline $\mathrm{Na}+\mathrm{K}-\mathrm{Cl}$ & 138 & 188 & 196 & 203 & 134 & 185 & 192 & 194 \\
\hline
\end{tabular}

'Vitamin and mineral mix supplied the following per kilogram of diet: vitamin $\mathrm{A}, 11,000 \mathrm{IU}$; vitamin D3, 1,800 IU; vitamin E, $11 \mathrm{mg}$; vitamin $\mathrm{K} 3,2 \mathrm{mg}$; vitamin B2, $5.7 \mathrm{mg}$; vitamin B6, 2 mg; vitamin B12, 0.024 mg; nicotinic acid, 28 mg; folic acid, 0.5 mg; pantothenic acid, 12 mg; choline chloride, 250 mg; Mn, 100 mg; Zn, 65 mg; Cu, 5 mg; Se, 0.22 mg; l,

$0.5 \mathrm{mg}$; and $\mathrm{Co}, 0.5 \mathrm{mg}$.

NPP: Non-phytate phosphorus

amylase: $700 \mathrm{U} / g$, cellulose: $6,000 \mathrm{U} / g$, pectinase: $700 \mathrm{U} / g$, xylanase: $10,000 \mathrm{U} / \mathrm{g}$, lipase: $30 \mathrm{U} / \mathrm{g}$ and protease: $3,000 \mathrm{U} / \mathrm{g}$ ) and showed that it improved protein utilization. Khalaji et al. (2011) determined the standardized ileal threonine equivalence values of the same enzyme mentioned above. The results of their experiment showed that addition of $0.5 \mathrm{~g}$ of this enzyme blend released, in average, $0.1 \%$ threonine from anti-nutrient protein complexes.

The objective of the present study was to determine the crude protein $(C P)$ equivalence of a recently developed multi-enzyme product (Natuzyme-P, containing phytase: $1000,000 \mathrm{U} / g, \beta$ glucanase: $700 \mathrm{U} / g, \alpha$-amylase: $700 \mathrm{U} / g$, cellulose: 6,000 U/g, pectinase: $700 \mathrm{U} / g$, xylanase: 10,000 U/g, lipase: 30 $\mathrm{U} / \mathrm{g}$ and protease: 3,000U/g) using linear and nonlinear equations.

\section{MATERIALS AND METHODS}

\section{General procedure}

Two experiments were carried out to estimate crude protein equivalence of the enzyme blend Natuzyme-p for broilers. Equivalence CP values of the product were estimated in two experiments. In each experiment, 160 feather-sexed male Ross 308 broilers were submitted to the dietary treatments between 0-28 (starter) and 28- 42 (grower) days of age.

Broilers with similar initial body weight were allotted to battery cages $\left(55 \times 85 \mathrm{~cm}, 0.94 \mathrm{~m}^{2} / \mathrm{bird}\right)$. Each cage was equipped with a feeder and drinker. A $24 \mathrm{~h}$ lighting program was employed, and feed and water were provided ad libitum. Soft plastic wires were placed on the cage floor to minimize foot lesions. 
The experiments were carried out according to a completely randomized design. Four replicates of five birds each were fed graded CP levels (four treatments) or product levels (four treatments) in each experiment. Feed intake and body weight were recorded at 28 and $42 \mathrm{~d}$ of age, and then feed conversion ratio (FCR) was calculated. Relative carcass, breast meat, gizzard, and abdominal fat pad weights were determined at slaughter.

\section{Dietary treatments}

\section{Experiment 1}

The objective of experiment 1 was to estimate $\mathrm{CP}$ equivalence values of the enzyme product when broilers were 28 and 42 days old. Graded CP levels were supplied in the starter (16, 18, 20 and $22 \%$ ) and grower (14, 16, 18 and 20\%) diets. Amino acid levels were kept similar between diets with different CP levels by adding synthetic amino acids, so that the only source of variation in this experiment was dietary CP level. Graded levels of the enzyme product $(0.15$, $0.25,0.35$ and $0.45 \mathrm{~g} / \mathrm{kg}$ ) were added to the basal diets (14 and $16 \%$ CP in starter and grower diets, respectively).

\section{Experiment 2}

Because in experiment 1, the regression equations between BW (or FCR) and CP levels were not fit to estimate CP equivalence value due to a possible deficiency of essential amino acids, another experiment was conducted to reevaluate $C P$ equivalence of the

Table 2 - Ingredients and nutritional composition of experimental diets (0-28 and 28-42 d of age, Exp. 2)

\begin{tabular}{|c|c|c|c|c|c|c|c|c|}
\hline \multirow[t]{2}{*}{ Ingredient } & \multicolumn{4}{|c|}{ Starter period (0-28 d of age) } & \multicolumn{4}{|c|}{ Grower period (28-42 d of age) } \\
\hline & 1 (basal diet) & 2 & 3 & 4 & 1 (basal diet) & 2 & 3 & 4 \\
\hline Corn & 752.7 & 671.5 & 604.4 & 558.5 & 803.3 & 722.6 & 710 & 656.5 \\
\hline Soybean Meal & 145.9 & 220.8 & 272.5 & 291.5 & 61.4 & 93.3 & 139.2 & 170 \\
\hline Corn gluten & 49.8 & 43.3 & 49.7 & 73.8 & 63.9 & 82.4 & 92 & 110.4 \\
\hline Rice Bran & 0 & 0 & 0 & 0 & 20 & 0 & 0 & 0 \\
\hline Corn oil & 4.5 & 18.9 & 28.2 & 30 & 7.7 & 8 & 15.7 & 20 \\
\hline Dicalcium Phosphate & 19.2 & 18.6 & 18.1 & 17.9 & 17 & 16.8 & 16.3 & 16 \\
\hline Oyster shell & 13.8 & 13.6 & 13.5 & 13.5 & 12.9 & 12.8 & 12.8 & 12.8 \\
\hline $\mathrm{NaCl}$ & 1.7 & 2.4 & 2.4 & 2.4 & 1.8 & 1.8 & 2.5 & 2.5 \\
\hline $\mathrm{NaHCO}_{3}$ & 2 & 1 & 1 & 1 & 2 & 2 & 1 & 1 \\
\hline Min. premix1 & 3 & 3 & 3 & 3 & 3 & 3 & 3 & 3 \\
\hline Vit. Premix1 & 3 & 3 & 3 & 3 & 3 & 3 & 3 & 3 \\
\hline D-L- Methionine & 0.5 & 0.9 & 1.2 & 2.3 & 0 & 0.1 & 0.3 & 0.4 \\
\hline L-Lysine & 3.8 & 3 & 2.9 & 4 & 4 & 4.2 & 4.2 & 4.4 \\
\hline L-Threonine & 0 & 0 & 0 & 0.1 & 0 & 0 & 0 & 0 \\
\hline \multicolumn{9}{|l|}{ Nutrient } \\
\hline AMEn & 3050 & 3050 & 3050 & 3050 & 3150 & 3150 & 3150 & 3150 \\
\hline Crude protein & 16 & 18 & 20 & 22 & 14 & 16 & 18 & 20 \\
\hline $\mathrm{Ca}$ & 0.95 & 0.95 & 0.95 & 0.95 & 0.85 & 0.85 & 0.85 & 0.85 \\
\hline NPP2 & 0.47 & 0.47 & 0.47 & 0.47 & 0.42 & 0.42 & 0.42 & 0.42 \\
\hline $\mathrm{Na}$ & 0.16 & 0.16 & 0.16 & 0.16 & 0.16 & 0.16 & 0.16 & 0.16 \\
\hline Lysine & 0.95 & 1.08 & 1.21 & 1.34 & 0.76 & 0.87 & 0.99 & 1.1 \\
\hline Met+Cys & 0.65 & 0.74 & 0.83 & 0.92 & 0.56 & 0.64 & 0.73 & 0.82 \\
\hline Threonine & 0.59 & 0.68 & 0.76 & 0.84 & 0.49 & 0.57 & 0.64 & 0.72 \\
\hline $\mathrm{Na}+\mathrm{K}-\mathrm{Cl}$ & 157 & 184 & 207 & 220 & 112 & 126 & 135 & 146 \\
\hline
\end{tabular}

'Vitamin and mineral mix supplied the following per kilogram of diet: vitamin A, 11,000 IU; vitamin D3, 1,800 IU; vitamin E, 11 mg; vitamin K3, 2 mg; vitamin B2, 5.7 mg; vitamin B6, 2 mg; vitamin B12, 0.024 mg; nicotinic acid, 28 mg; folic acid, 0.5 mg; pantothenic acid, 12 mg; choline chloride, 250 mg; Mn, 100 mg; Zn, 65 mg; Cu, 5 mg; Se, 0.22 mg; I, $0.5 \mathrm{mg}$; and Co, $0.5 \mathrm{mg}$.

NPP: Non-phytate phosphorus. 
Table 3 - Effects of dietary treatments on performance and carcass parameters (Exp. 1)

\begin{tabular}{|c|c|c|c|c|c|c|c|c|c|}
\hline \multicolumn{2}{|c|}{ Treatment } & $\begin{array}{c}\text { BW at } 28 \\
\mathrm{~d}(\mathrm{~g})\end{array}$ & $\begin{array}{c}\text { FCR at } 28 d \\
(\mathrm{~g} / \mathrm{g})\end{array}$ & $\begin{array}{c}\text { BW at } 42 \\
d(g)\end{array}$ & $\begin{array}{c}\text { FCR at } 42 \mathrm{~d} \\
(\mathrm{~g} / \mathrm{g})\end{array}$ & Carcass (\%) & $\begin{array}{c}\text { Abdominal } \\
\text { fat (\%) }\end{array}$ & Gizzard (\%) & $\begin{array}{c}\text { Breast meat } \\
(\%)\end{array}$ \\
\hline \multicolumn{10}{|c|}{ Protein levels } \\
\hline $0-28 d$ & $\begin{array}{c}28-42 \\
d\end{array}$ & & & & & & & & \\
\hline 22 & 20 & $1328.13^{a}$ & $1.33^{c}$ & $2543.60^{a}$ & $1.57^{c}$ & $57.27^{\mathrm{a}}$ & $1.43^{c}$ & $1.32^{b}$ & $24.42^{\mathrm{a}}$ \\
\hline 20 & 18 & $1168.75^{b}$ & $1.44^{b}$ & $2297.00^{b}$ & $1.65^{c}$ & $74.20^{\mathrm{ab}}$ & $2.14^{c}$ & $1.46^{\mathrm{ab}}$ & $23.38^{\mathrm{ab}}$ \\
\hline 18 & 16 & $1163.50^{\mathrm{b}}$ & $1.49^{b}$ & $2251.80^{b}$ & $1.74^{\mathrm{b}}$ & $72.50^{\mathrm{b}}$ & $2.46^{\mathrm{b}}$ & $1.24^{\mathrm{b}}$ & $23.42^{\mathrm{ab}}$ \\
\hline 16 & 14 & $935.75^{c}$ & $1.65^{a}$ & $1776.8^{c}$ & $1.97^{\mathrm{a}}$ & $72.80^{\mathrm{ab}}$ & $3.14^{\mathrm{a}}$ & $1.64^{\mathrm{a}}$ & $21.15^{b}$ \\
\hline \multicolumn{2}{|c|}{ SE } & 29.42 & 0.02 & 76.2 & 0.027 & 0.8 & 0.2 & 0.01 & 0.79 \\
\hline \multicolumn{10}{|c|}{ Enzyme levels } \\
\hline \multicolumn{2}{|c|}{0.45} & 935 & 1.65 & 1770 & 1.91 & 72.00 & 3.13 & 1.56 & 21.02 \\
\hline \multicolumn{2}{|c|}{0.35} & 963 & 1.59 & 1866.80 & 1.90 & 71.77 & 3.22 & 1.43 & 21.26 \\
\hline \multicolumn{2}{|c|}{0.25} & 1022 & 1.55 & 1780.20 & 2.01 & 72.25 & 3.08 & 1.46 & 20.42 \\
\hline \multicolumn{2}{|c|}{0.15} & 976.6 & 1.70 & 1826.50 & 2.07 & 72.15 & 2.85 & 1.54 & 19.13 \\
\hline \multicolumn{2}{|c|}{ SE } & 46.37 & 0.052 & 81 & 0.062 & 0.97 & 0.27 & 0.11 & 0.92 \\
\hline
\end{tabular}

${ }^{a-c}$ Means in the same column with no common superscript differ significantly $(P<0.05)$.

enzyme product, changing essential and non-essential amino acids (including Lys, Met+Cys and Thr; Table 2). However, the ratios between CP and amino acids were kept constant. Graded levels of the enzyme product were added to the basal diets, which contained $16 \%$ CP, $0.95 \%$ Lys, $0.65 \%$ Met +Cys and $0.59 \%$ Thr in starter period and 14\% CP, 0.76\% Lys,0.56\% Met + Cys and $0.49 \%$ Thr in grower period.

\section{Statistical Analysis}

Data were analyzed by the general linear models procedure of the SAS software (SAS Institute, 2003) with cage as experimental unit. Linear and quadratic effects of CP and enzyme product on body weight gain, feed conversion ratio and breast, thighs and abdominal fat weight percentage were tested using orthogonal polynomials. Linear and nonlinear response functions of body weight, feed conversion ratio and immune response that best fit the data were derived for CP and product levels. The models used were:

Linear function:

$$
Y=a+b X
$$

Nonlinear functions:

$$
\begin{aligned}
& Y=a+b 1 X+b 2 X 2 \\
& Y=a+b 1 X+b 2 X 2+b 3 X 3 \\
& Y=a(1-b(\text { expcx) }
\end{aligned}
$$

Where $Y=$ the responsedmeasurement and $X=C P$ levels (percentage of diet) or multi-enzyme product ( $g$ per $\mathrm{kg}$ of diet). Nonlinear or linear response equations with the highest $r^{2}$ value for added threonine and the equations for added multi-enzyme product were set to be equal and were solved using the procedure described by Yi et al. (1996).

\section{RESULTS}

\section{Experiment 1}

Performance and carcass data of broiler chicks fed different levels of CP and NP are presented in Table 3. Different dietary CP levels significantly influenced BW and FCR at 28 and $42 \mathrm{~d}$ of age. Even with similar levels of amino acids, diets with higher levels of CP resulted in higher BW at 28 and $42 \mathrm{~d}$ of age. Furthermore, as dietary levels of CP increased, broilers utilized their feed more efficiently compared to their counterparts received low CP diets, which deposited significantly more abdominal fat and also presented significantly lower breast meat yield compared with those fed higher dietary CP levels. The addition of different levels of the enzyme product did not significantly affect performance or carcass parameters. No linear and nonlinear equations between NP enzyme levels and BW fit, and therefore the results obtained in this experiment were not used to estimate $\mathrm{CP}$ equivalence values of the enzyme product.

\section{Experiment 2}

The influence of different levels of dietary $C P$ and amino acids on broiler performance (BW and FCR) and carcass parameters (carcass, abdominal fat, gizzard and breast meat relative weights) are presented in Table 4. At 28 and $42 \mathrm{~d}$ of age, broilers fed higher 
Table 4 - Effects of dietary treatments on performance and carcass parameters (Exp. 2)

\begin{tabular}{|c|c|c|c|c|c|c|c|c|c|}
\hline \multicolumn{2}{|c|}{ Treatment } & $\begin{array}{c}\text { BW at } 28 \\
\mathrm{~d}(\mathrm{~g})\end{array}$ & $\begin{array}{c}\text { FCR at } 28 d \\
(\mathrm{~g} / \mathrm{g})\end{array}$ & $\begin{array}{c}\text { BW at } 42 \\
d(g)\end{array}$ & $\begin{array}{c}\text { FCR at } 42 \mathrm{~d} \\
(\mathrm{~g} / \mathrm{g})\end{array}$ & Carcass (\%) & $\begin{array}{c}\text { Abdominal } \\
\text { fat (\%) }\end{array}$ & Gizzard (\%) & $\begin{array}{c}\text { Breast meat } \\
(\%)\end{array}$ \\
\hline \multicolumn{10}{|c|}{ Protein levels } \\
\hline $0-28 d$ & $28-42 d$ & & & & & & & & \\
\hline 22 & 20 & $1268.13^{a}$ & $1.42^{b}$ & $2417.25^{a}$ & $1.65^{c}$ & $72.17^{\mathrm{a}}$ & $2.06^{b}$ & 1.36 & $23.33^{\mathrm{a}}$ \\
\hline 20 & 18 & $1217.63^{a}$ & $1.48^{b}$ & $2267.98^{b}$ & $1.74 b^{c}$ & $73.30^{\mathrm{a}}$ & $2.13^{b}$ & 1.27 & $23.82^{\mathrm{a}}$ \\
\hline 18 & 16 & $1137.06^{b}$ & $1.49^{b}$ & $2109.05^{c}$ & $1.84^{b}$ & $71.59^{a}$ & $2.16^{b}$ & 1.37 & $21.88^{b}$ \\
\hline 16 & 14 & $973.94^{c}$ & $1.75^{\mathrm{a}}$ & $1767.18^{d}$ & $2.03^{a}$ & $69.42^{b}$ & $3.01^{a}$ & 1.48 & $20.27^{c}$ \\
\hline SE & & 23.8 & 0.03 & 28.8 & 0.03 & 0.68 & 0.18 & 0.08 & 0.33 \\
\hline \multicolumn{10}{|c|}{ Enzyme levels } \\
\hline \multicolumn{2}{|c|}{0.45} & 1048.94 & 1.62 & 1848.70 & $1.94^{b}$ & $70.25^{\mathrm{ab}}$ & 2.46 & 1.61 & 20.93 \\
\hline \multicolumn{2}{|c|}{0.35} & 984.69 & 1.67 & 1804.38 & $1.95^{\mathrm{ab}}$ & $70.88^{a}$ & 2.59 & 1.35 & 20.30 \\
\hline \multicolumn{2}{|c|}{0.25} & 1001.31 & 1.71 & 1787.18 & $2.03^{a}$ & $69.16^{\mathrm{b}}$ & 2.76 & 1.57 & 20.31 \\
\hline \multicolumn{2}{|c|}{0.15} & 956.75 & 1.64 & 1765.60 & $1.99^{\mathrm{ab}}$ & $69.79^{a b}$ & 2.69 & 1.43 & 19.78 \\
\hline \multicolumn{2}{|c|}{ SE } & 28.13 & 0.035 & 28.47 & 0.027 & 0.47 & 0.22 & 0.08 & 0.56 \\
\hline
\end{tabular}

acc Means in the same column with no common superscript differ significantly $(p<0.05)$.

protein and amino acid levels were significantly heavier than their counterparts fed low-density diets. The higher BW of these birds was associated with a more efficient utilization of the feed consumed. Although different levels of the tested enzyme product had no significant effect on broiler BW or FCR at 28 and 42 $\mathrm{d}$ of age, the equations fit these data and were used to estimate equivalence. In experiment two, enzyme supplementation resulted a numerical improvement in BW and FCR. Nonlinear response equations between graded levels of CP and the enzyme product with BW at 28 and $42 \mathrm{~d}$ of age are presented in Table 5. Crude protein equivalence values of Natuzyme-p enzyme during starter and grower period were estimated as 0.96 and $0.38 \%$ respectively.

\section{DISCUSSION}

It has been shown that enzyme complexes with multiple enzyme activities are able to improve broiler performance by increasing nutrient digestibility by interactions that occur among several enzymes. Zallena et al. (1999) and Meng \& Slominski (2005) reported higher protein and amino acid availability in corn-soybean meal diets supplemented with enzyme blends. The addition of different levels of the tested enzyme product to a low CP diet failed to influence either BW or FCR at any stage of broiler lifespan. In the first experiment, it seems that there was no influence of the tested product on broiler performance because the basal diet (which contained NP) was only deficient in CP when amino acids levels were kept at the recommended levels. Numerous studies have shown similar performance between broilers fed low CP diets supplemented with synthetic amino acids with those fed on diets with sufficient levels of CP (Par et al., 1991; Han et al., 1992; Namrud et al., 2008). Denbow et al. (1995), Harper et al. (1997) and Ravindran et al. (2001) used $R^{2}$ as the criterion for selecting either linear or non-linear regression models

Table 5 - Regression equations and estimated crude protein equivalence values of Natuzyme-p (Exp.2)

\begin{tabular}{cccccc} 
Trait & $\begin{array}{c}\text { Regression equation between } \\
\text { CP levels and BW }\end{array}$ & $R^{2}$ & $\begin{array}{c}\text { Regression equation between } \\
\text { enzyme levels and BW }\end{array}$ & $\begin{array}{c}R^{2} \\
\text { CP equivalence values of the } \\
\text { enzyme (\%) }\end{array}$ \\
\hline
\end{tabular}

BW at $28 d \quad Y=1.09 x^{3}-69.38 x^{2}+1491.2 x-9603.3 \quad 88 \quad Y=23677083 x^{3}-2081719 x^{2}+58720.6 x+464.4$

0.9647 
to describe the changes in certain response criteria to graded levels of phytase and supplemental inorganic phosphorous. The $\mathrm{R}^{2}$ values of linear and nonlinear models generated from the growth performance data in this experiment were lower than those observed in literature (Adedokun et al., 2004; Denbow et al., 1995; Ravindran et al., 2001; Yi et al., 1996). The differences may be attributed to the duration of the study and bird age. Denbow et al. (1995), Yi et al. (1996) and Ravindran et al. (2001) conducted 21 d trials, whereas the duration of our trial was $42 \mathrm{~d}$. Adedokun et al. (2004) applied only linear regression equation and obtained higher $\mathrm{R}^{2}$ values using phytase. However, the duration of their study was $14 \mathrm{~d}$ after allowing ad libitum access to a standard P-adequate starter diet for 7 days. However, in the present study, there were four weeks more, which allowed for higher variance as birds grew. Zaghari et al. (2008) showed the positive effect of a multi-enzyme product (containing phytase: $1500 \mathrm{U} / g$, beta-glucanase: $700 \mathrm{U} / \mathrm{g}$, alpha-amylase: $700 \mathrm{U} / g$, cellulose: 6,000 U/g, pectinase: $700 \mathrm{U} / \mathrm{g}$, xylanase: 10,000 U/g, lipase: $30 \mathrm{U} / g$ and protease: 3,000 U/g)on CP, which only difference to the blend used in the present experiment was phytase activity. In the current experiment the only source of variation between treatments was dietary CP level, while in previous experiment $C P$ levels varied along with other nutrients, including $A M E$, non-phytate $P$, and amino acids. Different responses may be therefore due both to different methodology and enzymes employed in the current experiment.

Based on the results obtained in the first experiment, the second experiment was designed so that CP levels varied together with amino acid levels. As expected, different dietary CP and amino acid levels resulted in significantly different performance responses at 28 and $42 \mathrm{~d}$ of age. These observations are consistent with those previously reported (Cheng, 1997; Kidd et al., 2004). The addition of different NP enzyme levels to the diet deficient both in amino acids and CP failed to influence BW and FCR at 28 and $42 \mathrm{~d}$ of age. As birds age, their amino acid requirements begin to decrease (Gao, 2007). It seems that the reduced amino acid requirements in later stages of broilers' lifespan are the primary reason for lack of response to NP enzyme addition. The lack of influence of exogenous enzymes on broiler performance during later growth stages (Zaghari et al., 2008) or in old birds (Denbow, 1995) is well documented.

\section{REFERENCES}

Adedokun SA, Sands JS, Adeola O. Determining the equivalent phosphorus released by an Escherichia coli-derived phytase in broiler chicks. Canadian Journal of Animal Science 2004; 84:437-444.

Cheng TK, Hamre ML, Coon CN. Response of broilers to dietary protein levels and amino acid supplementation to low protein diets at various temperatures. Journal of Applied Poultry Research 1997; 6: 18-33.

Cohelho MB, Kornegay ET. Phytase in animal nutrition and waste management. Mount Olive: Direi BASF Corp; 1996.

Denbow DM, Ravindran V, Kornegay ET, Yi Z, Hulet RM. Improving phosphorous availability in soybean meal for broilers by supplemental phytase. Poultry Science 1995; 74:1831-1842.

Gao F, Jiang Y, Zhou GH, Han ZK. The effects of xylanase supplementation on growth, digestion, circulating hormone and metabolite levels, immunity and gut microflora in chickens fed on wheat-based diets. Brithish Poultry Science 2007; 48(4):480-488.

Han Y, Suzuki H, Parsons CM, Baker DH. Amino acid fortification of a low protein corn - soybean meal diet for maximal weight gain and feed efficiency of the chick. Poultry Science 1992; 71:1168- 1178.

Harper AF, Kornegay ET, Schell TC. Phytase supplementation of lowphosphorous growing-finishing pig diets improve performance, phosphorous digestibility and bone mineralization and reduces phosphorous excretion. Journal of Animal Science 1997; 75:31743186.

Jendza JA, Dilger RN, Sands JS, Adeola O. Efficacy and equivalence of an Escherichia coli-derived phytase for replacing inorganic phosphorus in the diets of broiler chickens and young pigs. Journal of Animal Science 2006; 84:3364-3374

Khalaji S, Zaghari M, Shivazad M. Estimation of standardized ileal threonine equivalence values of a multi-enzyme and its effects on broiler chick's performance. Italian Journal of Animal Science. 2011; 10: 47-50.

Kidd MT, McDaniel CD, Branton SL, Miller ER, Boren BB, Fancher BI. Increasing amino acid density improves live performance and carcass yields of commercial broilers. Journal of Applied Poultry Research 2004; 13:593-604

Meng $X$, Slominski BA. Nutritive values of corn, soybean meal, canola meal, and peas for broiler chickens as affected by a multicarbohydrase preparation of cell wall degrading enzymes. Poultry Science 2005; $84: 1242-1251$

Namroud NF, Shivazad M, Zaghari M. Effects of Fortifying Low Crude Protein Diet with Crystalline Amino Acids on Performance, Blood Ammonia Level, and Excreta Characteristics of Broiler Chicks. Poultry Science 2008; 87:2250-2258.

Par J F, Summers JD. The effect of minimizing amino acid excesses in broiler diets. Poultry Science 1991; 70:1540-1549

Radcliff JS, Pleasant RS, Kornegay ET. Estimating equivalence values of microbial phytase for amino acids in growing and finishing pigs fitted with steered ileo-cecal valve cannulas. Journal of Animal Science 2006; 84:1119-1129.

Ravindran V, Selle PH, Ravindran GP, Morel CH, Kies AK, Bryden WL. Microbial phytase improves performance, apparent metabolisable energy and ileal amino acid digestibility of broiler fed a lysine-deficient diet. Poultry Science 2001; 80:338344

SAS Institute. SAS system for mixed models. Cary; 2003 
YiZ, Kornegay ET, Ravindran V, Denbow DM. Improving phytase phosphorus availability in corn and soybean meal for the broiler using microbial phytase and calculation of phosphorus equivalence values for phytase. Poultry Science 1996; 74:240-249.

Yu B, Chung TK. Effects of Multiple-Enzyme Mixtures on Growth Performance of Broilers Fed Corn-Soybean Meal Diets. Journal of Applied Poultry Research 2004; 13:178-182.

Zaghari M, Gaykani R, Shivazad M, Taherkhani R. Evaluation of Phytase nutrient equivalence for old laying hen. Asian journal Poultry Science 2008; 2(1); 24-29.

Zaghari M, Majdeddin M, Taherkhani R, Moravej H. Estimation of nutrient equivalence values of Natuzyme and its effects on broiler chick's performance. Journal of Applied Poultry Research 2008; 17:446-453.

Zanella I, Sakomura NK, Silversides FG, Fiqueirdo A, Pack M. Effect of enzyme supplementation of broiler diets based on corn and soybeans. Poultry Science $1997 ;$ 8:561-568. 
